\title{
Evaluating usability in educational technology: A systematic review from the teaching of mathematics
}

\author{
Odiel Estrada Molina, Dieter Reynaldo Fuentes-Cancell \\ and Alien García-Hernández
}

Universidad de las Ciencias Informáticas, Cuba

\begin{abstract}
The objective of this article is to determine which are the international standards and norms of usability that are used in educational technology applied to the teaching of mathematics at secondary and higher education levels, focused on two scenarios: (1) digital educational resources and virtual learning environments (VLEs), and (2) game-based learning. The PRISMA protocol was used and the Scopus and IEEE Xplorer databases, the Springer publishing House and the ACM Digital Library were used for the search strategy. Forty-seven primary studies were selected, emphasizing the use of the ISO/IEC 9241-11 standard. However, the isolated use of criteria to usability assessment without achieving engineering integration is reflected. Primary studies in the teaching of mathematics mainly use the ISO 9241-11:2018 and ISO/IEC 9126-1:2004 standards. Game-based learning scenario uses ISO 9241-11:2018 standards and procedures that guarantee, at least, the integration between efficiency, effectiveness, and ease of use. Digital educational resources and VLEs scenario uses ISO/IEC 9126-1:2004 and ISO/IEC 9241-11:2018 standards, and procedures that guarantee at least the integration between efficiency and ease of use; effectiveness and ease of use; ease of use and accessibility; and effectiveness, ease of use, accessibility, and efficiency.
\end{abstract}

\author{
ARTICLE DETAILS \\ LUMAT General Issue \\ Vol 10 No 1 (2022), 65-88 \\ Received 19 October 2021 \\ Accepted 18 January 2022 \\ Published 11 February 2022 \\ Pages: 24 \\ References: 78 \\ Correspondence: \\ oestrada@uci.cu \\ https://doi.org/10.31129/ \\ LUMAT.10.1.1686
}

Keywords: Educational technology, teaching of mathematics, systematic review, usability

\section{Introduction}

The diversity and specialization of new technologies applied to education (NTAEs) contribute to improving didactics. Pedagogical praxis is enriched through pedagogical and technological mediation, due to the characteristics of NTAE (interactivity, ubiquity, and virtuality, among others). This mediation depends on physiological, socioeconomic, and philosophical variables, among others (Almenara \& Gimeno, 2019; Hariyanto et al., 2020; Pallarès et al., 2018). The NTAEs are based on educational technology, the general systems theory, educational communication, psychopedagogy, and didactics. Examples of these technologies are: virtual learning environments (VLEs); educational computer systems and digital educational resources (learning objects, audio-visual materials, among others). Therefore, it is relevant to increase their effectiveness, for which fostering usability is a key issue. 
Usability is defined as the ease of use that a computer system and digital tools have according to a specific context, such as electronic commerce, business systems, and educational technologies (Nielsen \& Tahir, 2001). The use of usability in educational technologies is analyzed in various studies(Issa \& Jusoh, 2019; Kumar \& Mohite, 2018; Martinho et al., 2020; Mohd-Khir \& Ismail, 2019; Na \& Liu, 2019; YáñezGómez et al., 2019). In them, two trends are identified: the use of general usability evaluation criteria (present in the software engineering literature) and criteria specific to educational technology, known as pedagogical usability (Lopes \& Costa, 2018). These studies establish guidelines to guarantee the usability of educational technology (design and development) and criteria to verify the level of usability of these educational systems.

This quality criterion (usability) is explained by the ISO in two current standards: ISO/IEC 9126-1: 2004 (understandability, learnability, operability, and attractiveness) and ISO/IEC 9241-11: 2018 (effectiveness, efficiency, and satisfaction), as well as by the ISO/IEC 25010: 2011 norms (learnability, appropriateness, recognizability, operability, user error protection, user interface aesthetics and accessibility). Consequently, usability should be evaluated by features and metrics, that are used by both general computer systems (Nielsen \& Tahir, 2001) and specific systems related to a particular social context, for example, the NTAE mentioned above (Salas et al., 2019).

Although these technologies are oriented towards teaching and learning, and they depend, among other aspects, on the educational level, the characteristics of the students and the characteristics of the subjects being taught. In this scenario, mathematics stands out, as it contributes to the domain of logical, abstract, analytical, descriptive thought and the solution of basic and complex problems in science and everyday life. For this reason, assessing the usability of the technologies used in teaching this subject in a proper way is of vital importance. The specific didactics of this science is based on the discursive approach and realistic the teaching of mathematics; and is also characterized by reasoning, argumentation and demonstration, resolution of problems, together with modelling and argumentation (Sánchez et al., 2019).

It is relevant to assess the usability of the technologies used in the teaching of mathematics as they contribute to its learning. Various educational technologies allow, among other functionalities, the calculation, representation, and analysis of content related to analytical geometry, linear algebra, arithmetic calculation, and 
representation in $2 \mathrm{~d}$ and $3 \mathrm{D}$ (Alomari et al., 2020). For this reason, it is vital to determine how easy it is for the user (students and teachers) to use these digital technologies. In this sense, various studies research how to assess the usability of these educational technologies (Abuhlfaia \& de Quincey, 2019; Martinho et al., 2020).

\subsection{Literature review}

Various systematic reviews associated with the assessment of NTAEs' usability (sometimes called pedagogical usability) have been published (Alomari et al., 2020; Hamari et al., 2014; Holmes, 2006; Hooshyar et al., 2020; Kang et al., 2009; Klingenberg et al., 2019; Kumar \& Mohite, 2018; Martinho et al., 2020; Novak et al., 2012; Quiñones \& Rusu, 2017; Weinerth et al., 2014). However, they focus on general aspects of usability assessment, and not on specific topics such as the teaching of mathematics. For this reason, the objective of this article is to determine which are the international standards and norms of usability that are used in educational technology applied to the teaching of mathematics at secondary and higher education levels, focused on two scenarios: (1) digital educational resources and virtual learning environments (VLEs), and (2) game-based learning. The first scenario (digital educational resources and VLEs) is the main support of e-learning and b-learning. In addition, they are essential technologies and resources in face-to-face teaching. VLEs include digital educational resources, web pages, interaction, and collaboration tools and offer opportunities for indexing the digital products produced by third parties. The second scenario is chosen because game-based learning involves digital technologies that allow the development of educational games in $2 \mathrm{D}, 3 \mathrm{D}$ and immersive. In both scenarios, usability is expressed differently in correspondence to particularities of technologies and educational approaches.

Various systematic reviews have been published in the last 10 years. In the first reviews published on game-based learning usability assessment, the importance of classifying and adapting serious games to the characteristics of the student is highlighted. Martinho et al. (2020) focuses their review on gamification techniques and student motivation. They analyze the period from 2010 - 2019 centered on interaction, motivation, and feedback. Quiñones and Rusu (2017) establish an analysis of eight heuristics that, by trend, are used in serious games, analyzing 11 studies from the 2006-2016 period. Hooshyar et al. (2019) analyze 21 research works (2008-2017), focusing on artificial intelligence algorithms and their impact on effectiveness as a criterion of usability. Lastly, Kumar and Mohite (2018), review the 
2008-2016 period based on 23 papers, in which they declare criteria associated with human-computer interaction and user experience on mobile devices. Systematic reviews have also been published in conference proceedings, which include the usability criteria more frequently used in the period from 2010 to 2013 (Hamari et al., 2014).

Regarding digital educational resources and VLEs, systematic reviews have also been published. Kang et al. (2009) address the usability criteria for evaluating electronic books. Novak et al. (2012) establish the relationship between usability and student learning from the analysis of 16 studies. Freina and Ott (2015) delve into usability criteria from immersive virtual reality in education in studies published in the period from 2013 to 2014. Alomari et al. (2020) focus on user experience and user interface and their relationship with usability in VLE (period 2010-2018). Abuhlfaia and de Quincey (2019) focus their analysis on the assessment of usability in VLE from the student's perspective, for which reason they include a case study involving 101 students.

In the context of the teaching of mathematics, some systematic reviews have been published. Holmes (2006) describes the importance of evaluating the usability of interactive learning modules, verifying the criteria of ease of learning, effectiveness, and efficiency. Weinerth et al. (2014) analyze 24 papers to determine the usability of concept maps and their influence on learning, focusing on learnability. Drigas and Pappas (2015), focuses on the application of usability in learning mathematics through mobile devices. Klingenberg et al. (2019), analyze the usability criteria centered fundamentally on ergonomics and its relation with the protection of the sight of students.

The presented timeline of systematic reviews addresses the growing need to analyze the current state of usability assessment in the teaching of mathematics.

\section{Methods}

The PRISMA protocol (Urrútia \& Bonfill, 2010) and its dimensions for engineering (Torres-Carrion et al., 2018) were used, the indicators applied were:

1. Review method: Composed of four phases: (1) identification of research questions; selection, exclusion, and quality criteria; application of the search strategy and validity assessment; (2) analysis and determination of trends associated with usability criteria; (3) holding workshops with experts from the 
Distance Research Group of the National Center for Distance Education of Cuba and researchers from the Human-Computer Interaction Group (HCI Group) belonging to the University of Informatics Science, Cuba; and (4) paper writing. The method was applied from November 2020 to April 2021.

2. Research questions:

- Question 1: What international usability standards or norms are used by trend in the NTAEs applied to the teaching of mathematics at the secondary and higher education levels?

- Question 2: According to high impact systematic reviews, which international standards or norms associated with usability are used by trend in the NTAEs at the secondary and higher education levels?

- Question 3: What are the differences, if any, between the tendencies in questions 1 and 2 regarding usability assessment?

3. Selection and search strategy:

- Selection criteria for Question 1: articles and conference proceedings present at Scopus, ACM Digital Library, IEEE Xplore and Springer published from 2015 to April 2021; which are written in English and associated with the variables of question 1.

- Exclusion criteria of Question 1: articles, tutorials and papers with poor scientific basis will not be included, as well as those with limited structure designs or that do not justify or prove their results.

- Selection criteria for Question 2: only systematic review and/or bibliographic review articles will be chosen, since the central purpose of this question is to analyze the necessary and sufficient criteria associated with usability assessment of the secondary and higher education levels.

- Exclusion criteria for Question 2: Articles that do not explain the results obtained in the analysis of scientific literature. Research that does not search Scopus, WoS, IEEE Xplore, or ACM Digital Library. These databases and editorials are chosen because they index the largest number of scientific publications at the international level.

- Quality criteria: For questions 1 and 2, only papers that demonstrate the use of usability criteria will be included, with emphasis on those established in ISO / IEC 9126-1: 2004; ISO / IEC 9241-11: 2018; ISO / IEC 25010: 2011; and/or 
Nielsen heuristics (recommendations regarding usability). Nielsen heuristics are principles for web application design that include some usability criteria.

- Search strategies were based on the use of AND/OR logical operators and their combinations in Scopus, ACM Digital Library, IEEE Xplore, and/or Springer. The criteria used are illustrated in Table 1.

Table 1. Keywords and resulting search strings

\begin{tabular}{|c|c|}
\hline Keywords for Questions 1 and 2 & Keywords for question 1 \\
\hline $\begin{array}{l}\text { Usability; ISO/IEC 9126-1:2004 (synonymous ISO } \\
\text { 9126-1:2004); ISO/IEC 9241-11:2018(synonymous } \\
\text { ISO 9241-11:2018); ISO/IEC 25010:2011 } \\
\text { (synonymous ISO 25010:2011); educative } \\
\text { technology; digital educational; resources virtual } \\
\text { learning environments; learning objects; b-learning; } \\
\text { e-learning; m-learning; edugame; game-based } \\
\text { learning; secondary education; higher education; } \\
\text { gamification (synonymous serious game). }\end{array}$ & $\begin{array}{l}\text { Question 1: } \\
\text { Mathematics; mathematics } \\
\text { thinking; arithmetic skills; } \\
\text { geometric skills; algebraic } \\
\text { skills. }\end{array}$ \\
\hline General search strings & $\begin{array}{l}\text { Thematic areas in the search } \\
\text { string }\end{array}$ \\
\hline $\begin{array}{l}\text { Question } 1 \text { (Usability AND (ISO/IEC 9126-1:2004 OR } \\
\text { ISO 9126-1:2004) AND (ISO/IEC 9241-11:2018 OR } \\
\text { ISO 9241-11:2018) AND (ISO/IEC 25010:2011 OR ISO } \\
\text { 25010:2011) AND Educative technology AND Digital } \\
\text { educational resources AND Virtual learning } \\
\text { environments AND Learning objects AND B-learning } \\
\text { AND E-learning AND M-learning AND (game-based } \\
\text { learning OR Edugame) AND (Gamification OR Serious } \\
\text { game) AND Secondary education AND Higher } \\
\text { education AND Mathematics AND Mathematics } \\
\text { thinking AND Arithmetic skills AND Geometric skills } \\
\text { AND Algebraic skills). } \\
\text { Question } 2 \text { (Usability AND (ISO/IEC 9126-1:2004 OR } \\
\text { ISO 9126-1:2004) AND (ISO/IEC 9241-11:2018 OR } \\
\text { ISO 9241-11:2018) AND (ISO/IEC 25010:2011 OR ISO } \\
\text { 25010:2011) AND Educative technology AND Digital } \\
\text { educational resources AND Virtual learning } \\
\text { environments AND Learning objects AND B-learning } \\
\text { AND E-learning AND M-learning AND Edugame AND } \\
\text { (Gamification OR Serious game) AND Secondary } \\
\text { education AND Higher education) }\end{array}$ & $\begin{array}{l}\text { Question 1: } \\
\text { usability AND subject } \\
\text { area:("Applied Social Sciences" } \\
\text { OR "multidisciplinary" OR } \\
\text { "high education" OR } \\
\text { "education" OR "The teaching } \\
\text { of mathematics" OR " } \\
\text { mathematics teaching")) } \\
\text { Question 2: } \\
\text { usability AND subject } \\
\text { area:("Applied Social Sciences" } \\
\text { OR "multidisciplinary" OR } \\
\text { "high education" OR } \\
\text { "education")) }\end{array}$ \\
\hline
\end{tabular}

4. Validity assessment: to reduce the threat of internal validity, the Keywording technique was applied (Odun-Ayo et al., 2019). Regarding external validity, articles that did not justify their results were discarded. For analyzing 
conclusion validity, two procedures were applied: a form processed with the Keywording technique, and an assessment of the level of confidence in the validation of the hypotheses or the relationships between variables. For the validity of the construct, the review protocol discussed above was designed.

5. Data collection and analysis: for the selection of the primary studies, the following aspects were analyzed: abstracts, keywords, trends established in systematic reviews, the variables of the quasi-experiments, case studies, and the testing of their hypotheses (Muñoz \& Peralta, 2020). This process was oriented to determine the criteria and/or metrics of usability assessment that are used in the NTAEs at the secondary and higher education levels and those related to the teaching of mathematics.

6. Validity and reliability. A form is designed to evaluate each study. Each article is assessed (rating from 1 to 5 ) by the two researchers. In case of discrepancies, three researchers from the University of Informatics Science of Cuba review and evaluate these articles.

\section{Results}

In the search strategy (Figure 1), 51 primary studies (Figure 2 and Figure 3) were selected, 66.66\% indexed in Scopus, $17.54 \%$ in ACM Digital Library; 17.72\% in IEEE Xplore; and 1.96\% in Springer. For duplicate articles the following rules were applied (Equation 1, Equation 2, Equation 3):

\footnotetext{
$x$ (paper) $\in$ Scopus $\wedge$ IEEE Xplore $\wedge$ ACM Digital Library $\wedge$ Springer $\rightarrow \mathrm{x} \in$ Scopus group

$x$ (paper) $\in$ IEEE Xplore $\wedge$ ACM Digital Library $\wedge$ Springer $\rightarrow \mathrm{x} \in$ IEEE Xplore group

$x$ (paper) $\in$ ACM Digital Library $\wedge$ Springer $\rightarrow \mathrm{x} \in$ ACM Digital Librarygroup

Note: Any other case will be assigned to its corresponding group. 

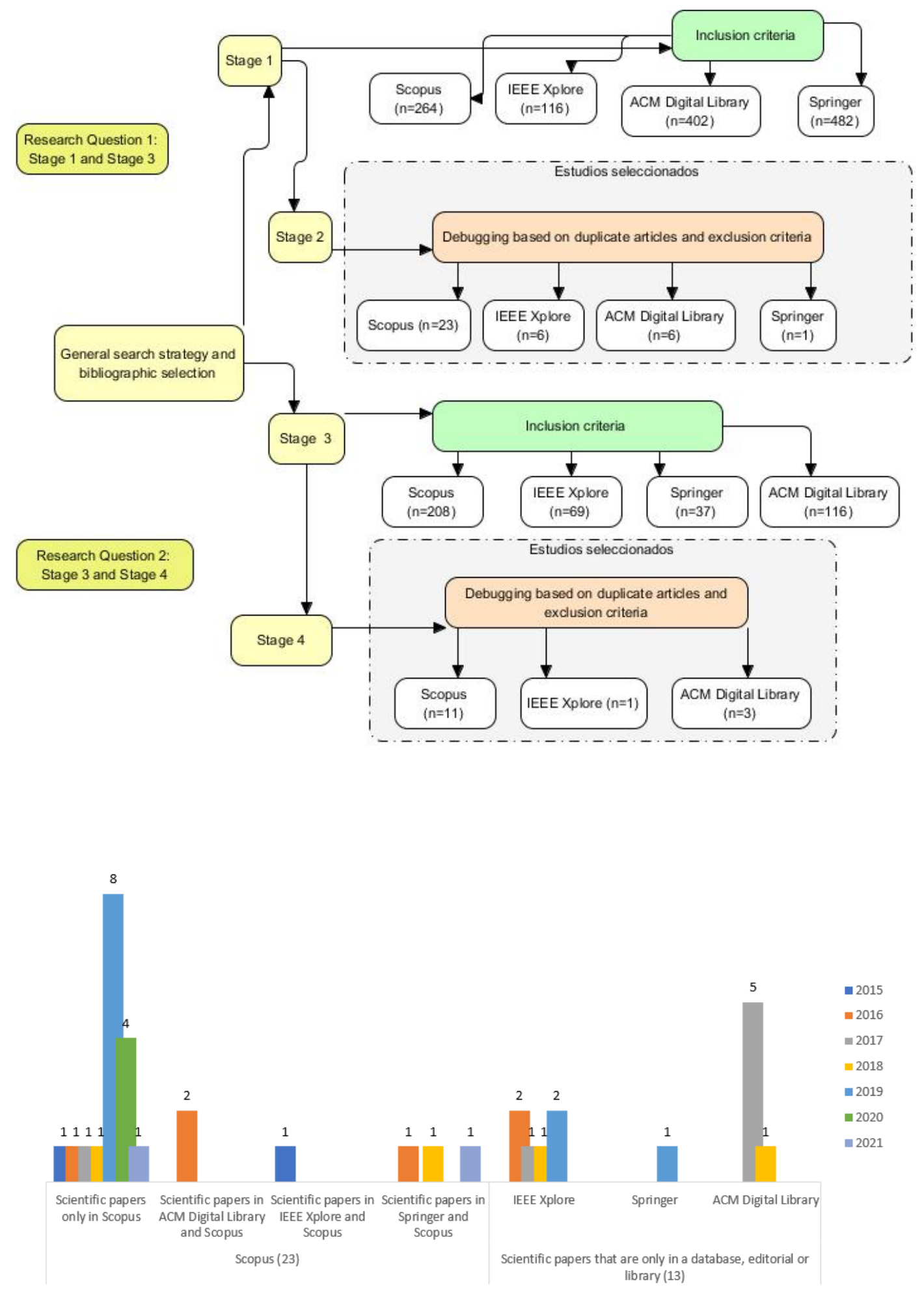


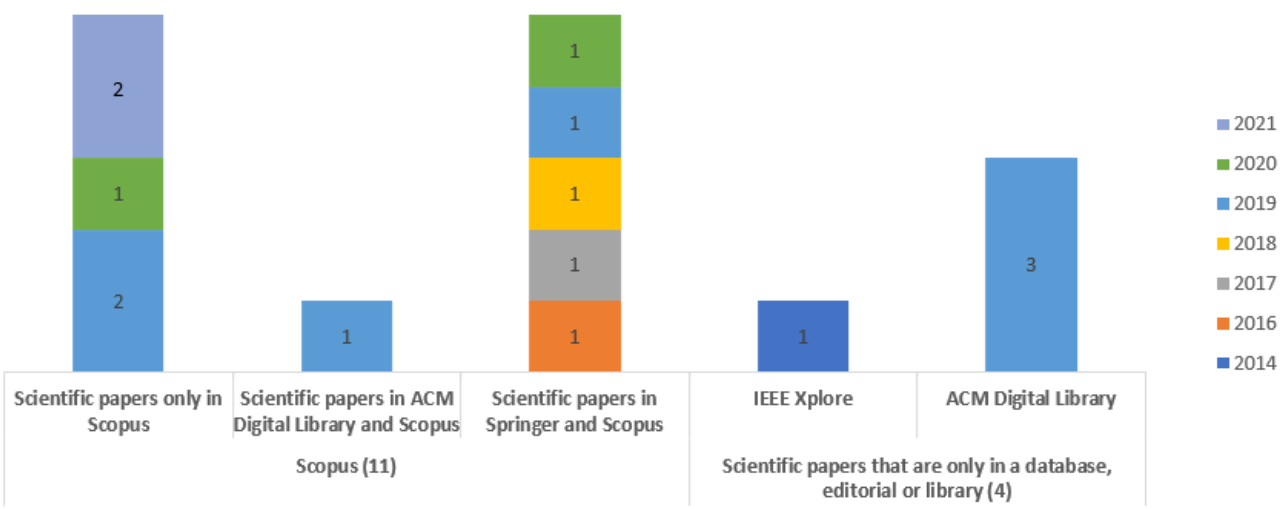

Regarding Question 1 (Table 2, Table 3, and Table 4), 41.66\% of primary studies uses the ISO/IEC 9241-11: 2018 standard; 11.11\% uses ISO/IEC 9126-1: 2004; 2.77\% uses the ISO/IEC 25010: 2011, and 44.46\% uses isolated criteria of usability addressed by authors (Nielsen heuristics in their recommendations associated with web usability) and/or standards and norms of the ISO. Regarding the type of study and design, the results were: case studies (61.76\%), descriptive or comparative studies (17.64\%), quasi-experiments (11.76\%), and theoretical studies $8.84 \%$.

Table 2. Research that applies ISO/IEC 9241-11: 2018

\begin{tabular}{ll}
\hline Research & Observations \\
\hline $\begin{array}{l}\text { Rumanová and Drábeková } \\
\text { (2017) }\end{array}$ & $\begin{array}{l}\text { Skills associated with production } \\
\text { possibilities frontiers }\end{array}$ \\
\hline Ibarra et al. (2017) & Gamification and game-based learning \\
\hline Pensabe-Rodriguez et al. (2020) & Developing skills in mathematics \\
\hline Martin-Gonzalez et al. (2016) & $\begin{array}{l}\text { Teaching of Euclidean vectors through } \\
\text { augmented reality }\end{array}$ \\
\hline Missen et al. (2019) & $\begin{array}{l}\text { Teaching mathematics and using mobile } \\
\text { applications }\end{array}$ \\
\hline Singh and Jha (2019) & Didactic work with Matlab \\
\hline Yağmur and Çakır (2016) & Teaching geometry through GeoGebra \\
\hline ibili et al. (2019) & Teaching geometry through augmented \\
\hline Wang et al. (2018) & reality \\
\hline dos Reis et al. (2019) & Educational experiences with the Algebra \\
\hline Bateman et al. (2018) & Nation \\
\hline Klingenberg et al. (2019) & Teamification and game-based learning \\
\hline
\end{tabular}


Table 3. Research that applies ISO/IEC 9126-1: 2004, ISO/IEC 25010: 2011 or ISO/IEC 9241-11: 2018

\begin{tabular}{|c|c|c|}
\hline Research & Usability criteria & Observations \\
\hline Ramírez-Vega et al. (2017) & ISO/IEC 9126-1:2004 & Massive Online Open Courses \\
\hline Casano et al. (2016) & ISO/IEC 9126-1:2004 & $\begin{array}{l}\text { Teaching of measurements and } \\
\text { geometry }\end{array}$ \\
\hline Wan-Sulaiman and Mustafa (2019) & $\begin{array}{l}\text { ISO/IEC 25010:2011; } \\
\text { ISO/IEC } 9126-1 \text { and ISO } \\
9241-11\end{array}$ & Digital books \\
\hline Varsaluoma et al. (2016) & $\begin{array}{l}\text { Isolated criteria of the } \\
\text { ISO/IEC 9241-11:2018; } \\
\text { ISO/IEC 9126-1:2004 }\end{array}$ & Microsoft Mathematics \\
\hline Ibarra et al. (2016) & $\begin{array}{l}\text { Isolated criteria of the } \\
\text { ISO/IEC 9241-11:2018; }\end{array}$ & Gamification \\
\hline Hadjerrouit and Gautestad (2019) & ISO/IEC 9126-1:2004 & Massive Online Open Courses \\
\hline Lopes and Costa (2018) & $\begin{array}{l}\text { Isolated criteria of the } \\
\text { ISO/IEC 9241-11:2018; }\end{array}$ & Teaching of general mathematics \\
\hline
\end{tabular}

Table 4. Research using isolated usability criteria

\begin{tabular}{|c|c|c|}
\hline Research & Usability criteria & Observations \\
\hline $\begin{array}{l}\text { Alshira, Al-omari, and Igried } \\
\text { (2021) }\end{array}$ & $\begin{array}{l}\text { Satisfaction, disability to use, efficiency, and } \\
\text { effectiveness }\end{array}$ & Curricular study \\
\hline Fonseca et al. (2020) & Efficiency, ease of use & Curricular study \\
\hline Ávila-Soto et al. (2017) & Accessibility & Arithmetic skills \\
\hline Chen (2018) & Efficiency, ease of use & $\begin{array}{l}\text { Discrete mathematics } \\
\text { teaching }\end{array}$ \\
\hline $\begin{array}{l}\text { Tomaschko and Hohenwarter } \\
\text { (2017) }\end{array}$ & $\begin{array}{l}\text { Efficiency, content, method, tasks or } \\
\text { activities, social interaction }\end{array}$ & Use of GeoGebra \\
\hline $\begin{array}{l}\text { Tsouccas and Meletiou- } \\
\text { Mavrotheris (2017) }\end{array}$ & $\begin{array}{l}\text { Efficiency, content, method, tasks or } \\
\text { activities, social interaction }\end{array}$ & Curricular study \\
\hline Ishaq et al. (2019) & $\begin{array}{l}\text { Effectiveness, tasks or activities, } \\
\text { pedagogical ease }\end{array}$ & $\begin{array}{l}\text { M-learning and } \\
\text { mathematical teaching }\end{array}$ \\
\hline Sarkar et al. (2019) & Effectiveness, satisfaction & Augmented reality \\
\hline Toda et al. (2015) & Efficiency, effectiveness, ease of use & $\begin{array}{l}\text { Gamification and } \\
\text { general mathematics } \\
\text { teaching }\end{array}$ \\
\hline Calderon et al. (2019) & Ease of use and pedagogical ease & \\
\hline Chang et al. (2017) & Efficiency, customization, pedagogical ease & Mathematical Thinking \\
\hline Awang et al. (2019) & Efficiency, effectiveness, ease of use & Augmented reality \\
\hline Beswick and Fraser (2019) & Ease of use, social interaction & Teacher training \\
\hline Bozkurt and Ruthven (2017) & Ease of use, accessibility, methods, content & Use of GeoGebra \\
\hline Pujiastuti et al. (2020) & Ease of use, accessibility, pedagogical ease & Interactive media \\
\hline Hadjerrouit and Gautestad (2019) & Ease of use, accessibility, pedagogical ease & Use of SimReal+ \\
\hline
\end{tabular}


These studies (Question 1) were grouped (Table 5) according to the two base scenarios of this article: Scenario 1: digital educational resources and VLEs and Scenario 2: game-based learning.

Table 5. Grouping of studies according to their regularities

\begin{tabular}{lc}
\hline Researches & Scenarios \\
\hline Hadjerrouit and Gautestad (2019); Casano et al. (2016); Chang et al. (2017); & \\
Martin-Gonzalez et al. (2016); Yağmur and Çakır (2016); Varsaluoma et al. & \\
(2016); Bozkurt and Ruthven (2017); Tomaschko and Hohenwarter (2017); & \\
Ávila-Soto et al. (2017); Ramírez-Vega et al. (2017); Rumanová and Drábeková & \\
(2017); Tsouccas and Meletiou-Mavrotheris (2017); Bateman et al. (2018); & Scenario 1 \\
Chen (2018); Wang et al. (2018); Singh and Jha (2019); Adnan et al. (2019); & \\
Beswick and Fraser (2019); Ishaq et al. (2019); ibili et al. (2019); Sarkar et al. & \\
(2019); Lopes and Costa (2018); Klingenberg et al. (2019); Pensabe-Rodriguez & \\
et al. (2020); Pujiastuti et al. (2020); Wan-Sulaiman and Mustafa (2019); & \\
Fonseca et al. (2020); Alshira, Al-omari, and Igried (2021) & Scenario 2 \\
\hline Toda et al. (2015); Ibarra et al. (2016); Ibarra et al. (2017); Calderon et al. & \\
\hline
\end{tabular}

It is evident that the ISO/IEC 9241-11 standard is the most frequently used in the teaching of mathematics. In turn, to contribute to the teaching of arithmetic, algebra, and mathematical thinking (variables with higher frequency in primary studies), the criteria of efficiency, ease of use and effectiveness are prioritized.

To answer Question 2, an analysis of 15 systematic reviews covering the period 2014-April 2021 (Table 6 and Table 7) was carried out. A greater frequency is observed when using the ISO/IEC 9241-11: 2018 standard, specifically, in the case of the efficiency and effectiveness characteristics. 
Table 6. Summary of learning scenarios addressed in systematic reviews.

\begin{tabular}{|c|c|c|c|}
\hline Research & Time lapse analyzed & Target audience & Scenarios \\
\hline $\begin{array}{l}\text { Vlachogianni and Tselios } \\
\text { (2021) }\end{array}$ & systematic review $2015-2020$ & & \multirow{7}{*}{$\begin{array}{l}\text { Scenario 1: } \\
\text { Digital } \\
\text { educational } \\
\text { resources } \\
\text { and VLE }\end{array}$} \\
\hline Law and Heintz (2021) & systematic review $2016-2020$ & General education & \\
\hline Alomari et al. (2020) & systematic review 2010-2018 & & \\
\hline $\begin{array}{l}\text { Abuhlfaia and de Quincey } \\
\text { (2019) }\end{array}$ & $\begin{array}{l}\text { systematic review (2015-2017) } \\
\text { and includes analysis of surveys }\end{array}$ & $18-48$ years & \\
\hline Na and Liu (2019) & $\begin{array}{l}\text { systematic review (2015-2018) } \\
\text { and includes analysis of surveys }\end{array}$ & \multirow{3}{*}{ General education } & \\
\hline Issa and Jusoh (2019) & $\begin{array}{l}\text { systematic review (2015-2017) } \\
\text { and includes analysis of surveys }\end{array}$ & & \\
\hline Kumar and Mohite (2018) & systematic review 2008-2016 & & \\
\hline Vieira et al. (2019) & systematic review 2014-2017 & General education & \multirow{8}{*}{$\begin{array}{l}\text { Scenario 2: } \\
\text { Game- } \\
\text { based } \\
\text { learning }\end{array}$} \\
\hline Quiñones and Rusu (2017) & systematic review 2006-2016 & General education & \\
\hline Yáñez-Gómez et al. (2019) & systematic review 2015-2019 & $10-24$ years & \\
\hline Yáñez-Gómez et al. (2017) & systematic review 2003-2015 & $7-11$ years & \\
\hline Khir and Ismail (2019) & $\begin{array}{l}\text { systematic review (2015 - 2017) } \\
\text { and includes analysis of surveys }\end{array}$ & Adult education & \\
\hline Martinho et al. (2020) & systematic review 2015-2019 & \multirow{3}{*}{ General education } & \\
\hline Hamari et al. (2014) & systematic review 2010-2013 & & \\
\hline Hooshyar et al. (2019) & systematic review 2008-2017 & & \\
\hline
\end{tabular}

It is evident in these systematic reviews that the graphical representation of the results obtained in the heuristic evaluation can use the Pearson's correlation coefficient (Equation 4).

$$
r=\frac{\sum_{i=1}^{n}\left(\left(x_{i}-\bar{x}\right)\left(y_{i}-\bar{y}\right)\right)}{\sum_{i=1}^{n}\left(y_{i}-\bar{y}\right)^{2} \sum_{i=1}^{n}\left(x_{i}-\bar{x}\right)^{2}}
$$

- Given two variables $\mathrm{x}$ and $\mathrm{y}, \mathrm{r}$ is calculated as a ratio of the variable's covariance to their standard deviations where $\mathrm{n}$ is the number of variables.

The Chi-Square goodness of fit test is used to assess the relationship between the variables associated with the Nielsen heuristics and the application of the characteristics of ISO/IEC 9241-11: 2018 (Equation 5), where $\mathrm{O}$ is the observed frequency of each categorical value and $\mathrm{E}$ is the expected frequency.

$$
X^{2}=\left((O-E)^{2} / E\right)
$$

Of these systematic reviews, $61.53 \%$ belong to the game-based learning scenario, where gameplay refers to motivational factors such as enjoyment, commitment, and fun. The following criteria are included to evaluate usability: "functional playability" 
-referred to control mechanisms and their relationship to the game-; the "structural playability" - related to the aesthetics of digital games (rules, strategy, among others) -the "audiovisual playability", and "social playability" associated with cooperation among users.

Table 7. Synthesis of the usability criteria present in the systematic reviews.

\begin{tabular}{|c|c|c|}
\hline Research & Highest frequency usability criteria & Evaluation methods and techniques \\
\hline $\begin{array}{l}\text { Vlachogianni and } \\
\text { Tselios (2021) }\end{array}$ & Efficiency, learnability, ease of use & System Usability Scale (SUS) \\
\hline Law and Heintz (2021) & Efficiency & \\
\hline Alomari et al. (2020) & ISO/IEC 9241-11:2018 & $\begin{array}{l}\text { Cognitive walkthrough; } \\
\text { questionnaires; Nielsen usability } \\
\text { heuristics }\end{array}$ \\
\hline $\begin{array}{l}\text { Abuhlfaia and de } \\
\text { Quincey (2019) }\end{array}$ & Efficiency, learnability, ease of use & System Usability Scale (SUS) \\
\hline Na and Liu (2019) & $\begin{array}{l}\text { Efficiency and effectiveness of } \\
\text { learning }\end{array}$ & A new evaluation method is proposed \\
\hline Issa and Jusoh (2019) & Learnability, motivation, and flexibility & Personalized interviews \\
\hline $\begin{array}{l}\text { Kumar and Mohite } \\
\text { (2018) }\end{array}$ & ISO/IEC 9241-11:2018 & $\begin{array}{l}\text { Observation guides, interviews, } \\
\text { surveys, and personalized } \\
\text { questionnaires } \\
\text { Nielsen usability heuristics and Game }\end{array}$ \\
\hline Vieira et al. (2019) & ISO/IEC 9241-11:2018 & $\begin{array}{l}\text { User Experience Satisfaction Scale } \\
\text { (GUESS) }\end{array}$ \\
\hline $\begin{array}{l}\text { Quiñones and Rusu } \\
\text { (2017) }\end{array}$ & ISO/IEC 9241-11:2018 & Nielsen usability heuristics \\
\hline $\begin{array}{l}\text { Yáñez-Gómez et al. } \\
\text { (2017) }\end{array}$ & $\begin{array}{l}\text { ISO 9241-11; Nielsen heuristics and } \\
\text { game usability associated with } \\
\text { functional, structural, audiovisual, and } \\
\text { social playability }\end{array}$ & $\begin{array}{l}\text { They defend the new term } \\
\text { "playability" }\end{array}$ \\
\hline $\begin{array}{l}\text { Yáñez-Gómez et al. } \\
\text { (2019) }\end{array}$ & ISO/IEC 9241-11:2018 & $\begin{array}{l}\text { SUS and End-User Usability } \\
\text { Questionnaire }\end{array}$ \\
\hline $\begin{array}{l}\text { Mohd-Khir and Ismail } \\
\text { (2019) }\end{array}$ & ISO/IEC 9241-11:2018 & End-User Usability Questionnaire \\
\hline Martinho et al. (2020) & Accessibility & Questionnaires \\
\hline Hamari et al. (2014) & Effectiveness and motivation & Questionnaires \\
\hline Hooshyar et al. (2019) & Efficiency & $\begin{array}{l}\text { Implementation of procedural } \\
\text { content generation algorithms to } \\
\text { improve efficiency }\end{array}$ \\
\hline
\end{tabular}

To answer Question 3 (Table 8), three axes were structured showing different criteria resulting from the analysis of questions 1 and 2. 
Table 8. Relationship between the usability criteria used.

Axis 1. Usability criteria that by trend are used in educational technology for teaching in secondary and higher education

Scenario: game-based learning

Scenario: Digital educational resources and VLE

- ISO 9241-11:2018.

- ISO 9241-11:2018

- Nielsen heuristics.

- Criteria associated with: functional

- Procedures that guarantee, at least, the integration between playability, structural playability, audio-

a) Efficiency, learnability, and ease of use visual playability, and social playability.

b) Efficiency and effectiveness of learning

c) Learnability, motivation, and flexibility.

Axis 2. Usability criteria most used in the evaluation of computer products associated with the teaching of mathematics

Scenario: game-based learning

- ISO 9241-11:2018.

- Procedures that guarantee, at least, the integration between efficiency, effectiveness, and ease of use.
Scenario: Digital educational resources and VLE

- ISO/IEC 9126-1:2004; ISO/IEC 25010; ISO/IEC 9241-11:2018.

- Procedures that guarantee, at least, the integration between

a) Efficiency and ease of use

b) Effectiveness and ease of use

c) Accessibility and ease of use

d) Effectiveness, ease of use, accessibility, and efficiency.

Axis 3. Usability criteria proposed in Axis 1 and that its use is limited in evaluating the usability of computer products associated with the teaching of mathematics

Scenario: game-based learning

- Criteria associated with: functional playability, structural playability, audiovisual playability, and social playability.

- Nielsen heuristics.
Scenario: Digital educational resources and VLE

- Procedures that guarantee, at least, the integration between

- Efficiency and effectiveness of learning

- Learnability, motivation, and flexibility.

\section{Discussion}

The assessment of NTAEs' usability has the following fundamental objectives: to assess the scope and functionality of the technologies applied to education; to evaluate the experience of teachers and students in their interactivity with these technologies (VLE, digital educational resources, among others); and to identify the specific problems of the NTAEs' design and the possibility of creating a suitable didactic design for active, interactive, and collaborative learning.

Usability criteria and assessment procedures used in the technologies applied to the teaching of mathematics, can be summarized as follows (according to the scenarios described above): 
- Scenario 1: There is evidence of a trend towards the use of the ISO/IEC 924111:2018 standard and specific criteria associated with interactivity (design of collaborative learning tools), and instructional assessment (simplicity, feedback, and effectiveness of assessment tools).

Regarding the assessment of the usability of digital educational resources and VLE, criteria are addressed in correspondence with the scientific results of the CHICO Group of the University of Castilla - La Mancha (Molina et al., 2018), and those presented by (Cocunubo-Suárez et al., 2018). These criteria are: "content" (expresses the relationship between accuracy, expressiveness, objective, and pedagogical content), "method" (oriented to the organization and adaptability of learning objects), "personalization" (learning sequence), "tasks or activities" (interactivity, adaptation, sequence, among others), "social interaction" (dialogue, sharing, interactivity), and "pedagogical ease" (collaborative learning model, among others).

In the case of resources (with an emphasis on multimedia, hypermedia, and digital learning objects), current research (Fernández Márquez et al., 2019), addresses the need to guarantee the use modification and adaptation of these resources made by other researchers; that is why, the usability assessment must be verified. However, the research analyzed in the teaching of mathematics lacks qualification criteria for this purpose.

The results obtained coincide with the studies published by Cáceres and PowSang (2019) and Weichbroth (2020). They state that the experiences in mlearning usability criteria are often confused with those of user experience, which delimits the relationship between theory and practice. There is a tendency to use isolated criteria of usability, which, from an engineering perspective, limits the scope of the development of computer products and its influence on the assessment of user-centered design, human-computer interaction, and the actual determination of usability attribute assessment. Finally, other controversial criteria found are: (1) there is a tendency to not declaring a definition of usability, and to use general methods and techniques in its assessment, without prior contextualization to the particularities of the teaching of mathematics; and (2) there is a tendency to not using an application programming interface (API) to improve usability, which is a current trend (Rauf et al., 2019). 
- Scenario 2: As observed in the 15 systematic reviews analyzed for Question 2, the use of design patterns and game mechanisms (time limits, resources, among others) is evident, and so were game interface patterns (medals, levels, and points) and game heuristics (modalities, didactic objectives, mathematical skills to be developed, and the relationship between fantasy and learning scenarios). However, in the primary studies analyzed, the usability criteria they use from ISO/IEC 9126-1: 2004, ISO 9241-11: 2018 and/or ISO/IEC 25010: 2011 are not contextualized to assess functional, structural, audio-visual, and social playability. It is vitally important that usability assessment considers the effectiveness and efficiency of the game, showing the progress of the player itself and the progress of the student. Contextualizing the efficacy criteria influences the aspects that allow evaluating whether the game contributes to active and affective learning, determining the cognitive and affective-emotional domain. It is concluded that the use of standards and norms for usability assessment in a computer product in the educational field is evident. The bibliography analyzed shows a growing demand associated with the fact that VLE, learning objects and gamification are designed with an increasingly interactive, immersive, open, and collaborative learning. The most frequently quoted articles related to usability assessment in computer products oriented to the teaching of mathematics (Bozkurt \& Ruthven, 2017; İbili et al., 2019; Wang et al., 2018)emphasize on the importance of using the SUS and GUESS scales and using evaluation focused on end users (in this case, students).

In the context of b-learning, e-learning, and m-learning; when evaluating different computer products, there is a tendency to use questionnaires prepared by the authors themselves. Therefore, it coincides with the results obtained in previous systematic reviews (Alalwan et al., 2020; Radianti et al., 2020) carried out in other educational contexts. This is controversial since, in our case, none of the research works mentions or explains the process of validating the reliability of the questionnaire used.

There is a tendency in the studies consulted (with emphasis on the teaching of mathematics) to use usability criteria from the standards established in the ISO; although sometimes they only use some criteria in isolation. In turn, "classical and general" techniques and methods are properly applied to assess usability; but, from the point of view of this author, they lack contextualization to their social setting (teaching of mathematics). Their procedures do not address current trends (García et al., 2011; Pérez et al., 2019; Ramanayaka et al., 2018) that include artificial 
intelligence as a complement to methods and/or techniques (fuzzy analytic hierarchy process, technique for order preference by simulation of ideal solution, fuzzy analytical network process, and fuzzy cognitive maps, among others).

\section{Limitations}

The main limitation of this systematic review is the selection of only 51 primary studies. Nevertheless, the selected papers are relevant in their area of knowledge and indexed in prestigious databases and publishers. The article does not determine the criteria for assessing usability in the field of the teaching of mathematics, but it offers a theoretical approach and invites the scientific community to enrich these results.

Another limitation is only the analysis of literature written in English. Therefore, the analysis of articles written in other languages such as Spanish and Portuguese is primordial.

Finally, the main limitation is not to argue the pedagogical and didactic implications of the theoretical and practical deficiencies found in this review associated with the usability assessment of computer products (Table 8). That is, what pedagogical and didactic implications do the limitations found in the scientific literature related to the usability assessment of computer products (digital educational resources, VLEs, learning objects, among others) to be used in the teaching of mathematics entail? This question is, in turn, the main future work.

\section{Conclusions and future work}

The analysis of 15 systematic reviews associated with usability standards that are frequently used in the NTAEs at the secondary and higher education levels, are

- Game-based learning scenario uses ISO 9241-11: 2018 standards and the criteria associated with functional playability, structural playability, audiovisual playability, and social playability.

- Digital educational resources and VLEs scenario use ISO 9241-11:2018 standards and the procedures that guarantee at least the integration between efficiency, learnability, and ease of use; efficiency and effectiveness of learning; and learnability, motivation, and flexibility.

In this systematic review of the use of usability teaching criteria in the field of the teaching of mathematics, we include 36 studies and examine the trends and outcomes 
of usability assessment criteria studies. Primary studies in the teaching of mathematics mainly use the ISO 9241-11:2018 and ISO/IEC 9126-1:2004 standards. Regarding the two scenarios analyzed, it was concluded that:

- Game-based learning scenario uses ISO 9241-11:2018 standards and procedures that guarantee, at least, the integration between efficiency, effectiveness, and ease of use.

- Digital educational resources and VLEs scenario uses ISO/IEC 9126-1:2004 and ISO/IEC 9241-11:2018 standards, and procedures that guarantee at least the integration between efficiency and ease of use; effectiveness and ease of use; ease of use and accessibility; and effectiveness, ease of use, accessibility, and efficiency.

The systematic review shows inconsistencies between the criteria established in the primary studies of the teaching of mathematics and the results that reflect the published systematic reviews of secondary and higher education. They coincide with the use of the ISO 9241-11: 2018 and ISO/IEC 9126-1: 2004 standards, differing in the criteria for assessing usability in game-based learning (functional playability, structural playability, audiovisual playability, and social playability), and the criteria for assessing the usability of digital educational resources and VLEs (relationship between efficiency and effectiveness of learning, and among learnability, motivation, and flexibility).

In general, a theoretical framework is established to inform our findings of the status of the use of usability assessment criteria in the field of the teaching of mathematics, focused on two scenarios: digital educational resources and VLEs gamebased learning. Useful results are provided for future research in the teaching of mathematics. An example of this kind of result is the design of procedures to assess usability in the two key scenarios of this systematic review, which includes all the criteria and characteristics of a certain standard and others that the researcher considers appropriate in the educational context.

\section{Funding}

This research was supported by the University of Informatics Science, Cuba; the Project: ICTs that support educational processes and knowledge management in higher education (ELINF) and the Interuniversity Network for International 
Cooperation: Strengthening of the role.

\section{References}

Abuhlfaia, K., \& de Quincey, E. (2019). Evaluating the usability of an e-learning platform within higher education from a student perspective. ACM International Conference Proceeding Series, 1-7. https://doi.org/10.1145/3371647.3371661

Adnan, M., Abdullah, J. M., Ibharim, L. F. M., Hoe, T. W., Janan, D., Abdullah, N., Idris, N., Wahab, A. S. A., Othman, A. N., Hashim, M. E. A., Said, N. M., Adnan, R., Yahaya, S., Amin, N., Noh, M. A. M., Sufa'at, N. I., Abdullah, R., Yusof, Y., Reduaan, Z. A. M., ... Baharudin, N. F. A. (2019). Expanding opportunities for science, technology, engineering and mathematics subjects teaching and learning: Connecting through comics. Malaysian Journal of Medical Sciences, 26(4), 127-133. https://doi.org/10.21315/mjms2019.26.4.15

Alalwan, N., Cheng, L., Al-Samarraie, H., Yousef, R., Ibrahim Alzahrani, A., \& Sarsam, S. M. (2020). Challenges and Prospects of Virtual Reality and Augmented Reality Utilization among Primary School Teachers: A Developing Country Perspective. Studies in Educational Evaluation, 66, 100876. https://doi.org/10.1016/J.STUEDUC.2020.100876

Almenara, J. C., \& Gimeno, A. M. (2019). Las TIC y la formación inicial de los docentes. Modelos y competencias digitales. Profesorado, Revista de Currículum y Formación Del Profesorado, 23(3), 247-268. https://doi.org/10.30827/PROFESORADO.V23I3.9421

Alomari, H. W., Ramasamy, V., Kiper, J. D., \& Potvin, G. (2020). A User Interface (UI) and User eXperience (UX) evaluation framework for cyberlearning environments in computer science and software engi

neering education. Heliyon, 6(5). https://doi.org/10.1016/J.HELIYON.2020.E03917

Alshira, M., Al-omari, M., \& Igried, B. (2021). Usability Evaluation of Learning Management Systems ( LMS ) based on User Experience Turkish Journal of Computer and Mathematics Education Research Article. Turkish Journal of Computer and Mathematics Education (TURCOMAT), 12(11), 6431-6441.

https://www.turcomat.org/index.php/turkbilmat/article/view/7031

Ávila-Soto, M., Valderrama-Bahamóndez, E., \& Schmidt, A. (2017). TanMath: A tangible math application to support children with visual impairment to learn basic arithmetic. $A C M$ International Conference Proceeding Series, Part F128530, 244-245.

https://doi.org/10.1145/3056540.3064964

Awang, K., Shamsuddin, S. N. W., Ismail, I., Rawi, N. A., \& Amin, M. M. (2019). The usability analysis of using augmented reality for linus students. Indonesian Journal of Electrical Engineering and Computer Science, 13(1), 58-64.

https://doi.org/10.11591/IJEECS.V13.I1.PP58-64

Bateman, A., Zhao, O. K., Bajcsy, A. V., Jennings, M. C., Toth, B. N., Cohen, A. J., Horton, E. L., Khattar, A., Kuo, R. S., Lee, F. A., Lim, M. K., Migasiuk, L. W., Renganathan, R., Zhang, A., \& Oliveira, M. A. (2018). A user-centered design and analysis of an electrostatic haptic touchscreen system for students with visual impairments. International Journal of HumanComputer Studies, 109, 102-111. https://doi.org/10.1016/J.IJHCS.2017.09.004

Beswick, K., \& Fraser, S. (2019). Developing mathematics teachers' 21st century competence for teaching in STEM contexts. ZDM - Mathematics Education, 51(6), 955-965. https://doi.org/10.1007/s11858-019-01084-2

Bozkurt, G., \& Ruthven, K. (2017). Classroom-based professional expertise: a mathematics teacher's practice with technology. Educational Studies in Mathematics, 94(3), 309-328. https://doi.org/10.1007/s10649-016-9732-5 
Cáceres, S. V., \& Pow-Sang, J. A. (2019). A systematic mapping review of usability evaluation methods for educational applications on mobile devices. Applications in Software Engineering - Proceedings of the 7th International Conference on Software Process Improvement, CIMPS 2018, 59-68. https://doi.org/10.1109/CIMPS.2018.8625629

Calderon, C. A., Guajala, M., Lanchi, J., Barba-Guaman, L., Bermeo, C., \& Rivas-Echeverria, F. (2019). A machine vision system applied to the teaching of mathematics for blind or visually impaired children. IEEE ICA-ACCA 2018 - IEEE International Conference on Automation/23rd Congress of the Chilean Association of Automatic Control: Towards an Industry 4.O - Proceedings. https://doi.org/10.1109/ICA-ACCA.2018.8609818

Casano, J., Tee, H., Agapito, J., Arroyo, Í., \& Rodrigo, M. M. T. (2016). Migration and evaluation of a framework for developing embodied cognition learning games. Proceedings of the 3 rd Asia-Europe Symposium on Simulation and Serious Gaming - 15th ACM SIGGRAPH Conference on Virtual-Reality Continuum and Its Applications in Industry, VRCAI 2016, 199-203. https://doi.org/10.1145/3014033.3014035

Chang, C., Chin, Y. L., \& Chang, C. K. (2017). Experimental Functionality Development for Scratch Mathematical and Statistics Extensions. Proceedings - 2016 International Computer Symposium, ICS 2016, 640-644. https://doi.org/10.1109/ICS.2016.0131

Chen, Q. (2018). An application of online exam in discrete mathematics course. ACM International Conference Proceeding Series, 91-95.

https://doi.org/10.1145/3210713.3210734

Cocunubo-Suárez, J. I., Parra-Valencia, J. A., Otálora-Luna, J. E., Cocunubo-Suárez, J. I., ParraValencia, J. A., \& Otálora-Luna, J. E. (2018). Evaluation of Virtual Teaching-Learning Environments based on usability standards. TecnoLógicas, 21(41), 135-147.

dos Reis, T. S., Miranda, R. C., \& Filho, A. D. P. (2019). Usability of software of teaching aid in the teaching process mathematics learning. International Journal of Information and Education Technology, 9(5), 384-389. https://doi.org/10.18178/IJIET.2019.9.5.1232

Drigas, A., \& Pappas, M. (2015). A Review of Mobile Learning Applications for Mathematics. International Journal of Interactive Mobile Technologies (IJIM), 9(3), 18-23.

https://online-journals.org/index.php/i-jim/article/view/4420

Fernández Márquez, E., Ordóñez Olmedo, E., \& Morales Cevallos Jesús López Belmonte, B. (2019). La competencia digital en la docencia universitaria. Ediciones OCTAEDRO, S.L. https://octaedro.com/wp-content/uploads/2019/10/16154-La-competencia-digital-en-ladocencia-universitaria.pdf

Fonseca, D., García-Peñalvo, F. J., \& Camba, J. D. (2020). New methods and technologies for enhancing usability and accessibility of educational data. Universal Access in the Information Society 2020 2O:3, 2O(3), 421-427. https://doi.org/10.1007/S10209-02000765-0

Freina, L., \& Ott, M. (2015). A Literature Review on Immersive Virtual Reality in Education: State Of The Art and Perspectives. Scientific Conference Elearning and Software for Education, 133-150. http://www.google.com/patents/US3050870

García, J., García-Peñalvo, F. J., Therón, R., \& Ordoñez De Pablos, P. (2011). Usability Evaluation of a Visual Modelling Tool for OWL Ontologies. Journal of Universal Computer Science, $17(9), 1299-1313$.

http://www.jucs.org/jucs_17_9/usability_evaluation_of_a/jucs_17_09_1299_1313_garcia. pdf

Hadjerrouit, S., \& Gautestad, H. H. (2019). Evaluating the Usefulness of the Visualization Tool SimReal+ for Learning Mathematics: A Case Study at the Undergraduate Level. Learning Technologies for Transforming Large-Scale Teaching, Learning, and Assessment, 71-89. https://doi.org/10.1007/978-3-030-15130-0_5 
Hamari, J., Koivisto, J., \& Sarsa, H. (2014). Does gamification work? - A literature review of empirical studies on gamification. Proceedings of the Annual Hawaii International Conference on System Sciences, 3025-3034. https://doi.org/10.1109/HICSS.2014.377

Hariyanto, D., Triyono, M. B., \& Köhler, T. (2020). Usability evaluation of personalized adaptive elearning system using USE questionnaire. Knowledge Management and E-Learning, 12(1), 85-105. https://doi.org/10.34105/J.KMEL.2020.12.005

Holmes, M. H. (2006). Integrating the Learning of Mathematics and Science Using Interactive Teaching and Learning Strategies. Journal of Science Education and Technology 2006 15:3, 15(3), 247-256. https://doi.org/10.1007/S10956-006-9011-9

Hooshyar, D., Pedaste, M., Saks, K., Leijen, Ä., Bardone, E., \& Wang, M. (2020). Open learner models in supporting self-regulated learning in higher education: A systematic literature review. Computers \& Education, 154, 103878.

https://doi.org/10.1016/J.COMPEDU.2020.103878

Hooshyar, D., Yousefi, M., \& Lim, H. (2019). A systematic review of data-driven approaches in player modeling of educational games. In Artificial Intelligence Review (Vol. 52, Issue 3, pp. 1997-2017). Springer. https://doi.org/10.1007/s10462-017-9609-8

Ibarra, M. J., Mamani, Y., Ataucusi, P. E., Palomino, C., \& Ibañez, V. (2017). Raising students motivation for math learning using computer animation approach. 2017 43rd Latin American Computer Conference, CLEI 2017, 2017-January, 1-9.

https://doi.org/10.1109/CLEI.2017.8226436

Ibarra, M. J., Soto, W., Ataucusi, P., \& Ataucusi, E. (2016). MathFraction: Educational serious game for students motivation for math learning. Proceedings - 2016 11th Latin American Conference on Learning Objects and Technology, LACLO 2016.

https://doi.org/10.1109/LACLO.2016.7751777

İbili, E., Çat, M., Resnyansky, D., Şahin, S., \& Billinghurst, M. (2019). An assessment of geometry teaching supported with augmented reality teaching materials to enhance students' $3 \mathrm{D}$ geometry thinking skills. International Journal of Mathematical Education in Science and Technology , 51(2), 224-246. https://doi.org/10.1080/0020739X.2019.1583382

Ishaq, K., Zin, N. A. M., Rosdi, F., Abid, A., \& Farooq, U. (2019, November 1). Effectiveness of Literacy Numeracy Drive (LND): A Students' Perspective. 3rd International Conference on Innovative Computing, ICIC 2019. https://doi.org/10.1109/ICIC48496.2019.8966738

Issa, L., \& Jusoh, S. (2019). Usability evaluation on gamified e-learning platforms. ACM International Conference Proceeding Series. https://doi.org/10.1145/3368691.3368702

Kang, Y. Y., Wang, M. J. J., \& Lin, R. (2009). Usability evaluation of E-books. Displays, 3o(2), 4952. https://doi.org/10.1016/J.DISPLA.2008.12.002

Klingenberg, O. G., Holkesvik, A. H., \& Augestad, L. B. (2019). Digital learning in mathematics for students with severe visual impairment: A systematic review: British Journal of Visual Impairment, 38(1), 38-57. https://doi.org/10.1177/0264619619876975

Kumar, B. A., \& Mohite, P. (2018). Usability of mobile learning applications: a systematic literature review. Journal of Computers in Education, 5(1), 1-17.

https://doi.org/10.1007/s40692-017-0093-6

Law, E. L. C., \& Heintz, M. (2021). Augmented reality applications for K-12 education: A systematic review from the usability and user experience perspective. International Journal of Child-Computer Interaction, 30, 100321. https://doi.org/10.1016/J.IJCCI.2021.100321

Lopes, J. B., \& Costa, C. (2018). Digital Resources in Science, Mathematics and Technology Teaching - How to Convert Them into Tools to Learn. In Technology and Innovation in Learning, Teaching and Education. TECH-EDU 2018 (Vol. 993, pp. 243-255). Springer, Cham. https://doi.org/10.1007/978-3-030-20954-4_18 
Martin-Gonzalez, A., Chi-Poot, A., \& Uc-Cetina, V. (2016). Usability evaluation of an augmented reality system for teaching Euclidean vectors. Innovations in Education and Teaching International, 53(6), 627-636. https://doi.org/10.1080/14703297.2015.1108856

Martinho, D., Carneiro, J., Corchado, J. M., \& Marreiros, G. (2020). A systematic review of gamification techniques applied to elderly care. Artificial Intelligence Review, 53(7), 48634901. https://doi.org/10.1007/S10462-020-09809-6

Missen, M. M. S., Javed, A., Asmat, H., Nosheen, M., Coustaty, M., Salamat, N., \& Prasath, V. B. S. (2019). Systematic review and usability evaluation of writing mobile apps for children. New Review of Hypermedia and Multimedia, 25(3), 137-160. https://doi.org/10.1080/13614568.2019.1677787

Mohd-Khir, N. H. B., \& Ismail, M. (2019). Review on gamification in children computer interaction (CCI) for persona modelling. Bulletin of Electrical Engineering and Informatics, 8(4), 1411-1417. https://doi.org/10.11591/eei.v8i4.1622

Molina, A. I., Arroyo, Y., Lacave, C., \& Redondo, M. A. (2018). Learn-CIAN: A visual language for the modelling of group learning processes. British Journal of Educational Technology, 49(6), 1096-1112. https://doi.org/10.1111/BJET.12680

Muñoz, M., \& Peralta, M. (2020). Situación actual sobre la implementación del perfil básico ISO/IEC 29110 en EMP: una revisión sistemática de la literatura. RISTI - Revista Ibérica de Sistemas e Tecnologias de Informação, 36, 1-14. https://doi.org/10.17013/RISTI.36.1-14

$\mathrm{Na}$, J., \& Liu, Y. (2019). A quantitative revision method to improve usability of self and peer assessment in MOOCs. ACM International Conference Proceeding Series.

https://doi.org/10.1145/3321408.3322846

Nielsen, J., \& Tahir, M. (2001). Homepage Usability: 50 Websites Deconstructed. New Riders Publishing. https://www.todostuslibros.com/libros/homepage-usability_978-0-7357-1102-0

Novak, E., Razzouk, R., \& Johnson, T. E. (2012). The educational use of social annotation tools in higher education: A literature review. The Internet and Higher Education, 15(1), 39-49. https://doi.org/10.1016/J.IHEDUC.2011.09.002

Odun-Ayo, I., Goddy-Worlu, R., Yahaya, J., \& Geteloma, V. (2019). A systematic mapping study of cloud policy languages and programming models. In Journal of King Saud University Computer and Information Sciences, 33(7), 761-768. Elsevier.

https://doi.org/10.1016/j.jksuci.2019.05.003

Pallarès, M., Óscar, P., Bartoll, C., López, R., Ismael, M., \& Fayos, C. (2018). La escuela que llega. Tendencias y nuevos enfoques metodológicos (Primera edición). Octaedro. www.octaedro.com

Pensabe-Rodriguez, A., Lopez-Dominguez, E., Hernandez-Velazquez, Y., Dominguez-Isidro, S., \& De-la-Calleja, J. (2020). Context-aware mobile learning system: Usability assessment based on a field study. Telematics and Informatics, 48, 101346.

https://doi.org/10.1016/J.TELE.2020.101346

Pérez, Y. F., Corona, C. C., \& Estrada, A. F. (2019). Fuzzy Cognitive Maps for Evaluating Software Usability. Studies in Fuzziness and Soft Computing, 377, 141-155.

https://doi.org/10.1007/978-3-030-10463-4_8

Pujiastuti, H., Utami, R. R., \& Haryadi, R. (2020). The development of interactive mathematics learning media based on local wisdom and 21st century skills: social arithmetic concept. Journal of Physics: Conference Series, 1521(3), 032019. https://doi.org/10.1088/17426596/1521/3/032019

Quiñones, D., \& Rusu, C. (2017). How to develop usability heuristics: A systematic literature review. Computer Standards \& Interfaces, 53, 89-122.

https://doi.org/10.1016/J.CSI.2017.03.009 
Radianti, J., Majchrzak, T. A., Fromm, J., \& Wohlgenannt, I. (2020). A systematic review of immersive virtual reality applications for higher education: Design elements, lessons learned, and research agenda. Computers \& Education, 147, 103778.

https://doi.org/10.1016/J.COMPEDU.2019.103778

Ramanayaka, K. H., Chen, X., \& Shi, B. (2018). UNSCALE: A Fuzzy-based Multi-criteria Usability Evaluation Framework for Measuring and Evaluating Library Websites. IETE Technical Review, 36(4), 412-431. https://doi.org/10.1080/02564602.2018.1498032

Ramírez-Vega, A., Iniesto, F., \& Rodrigo, C. (2017). Raising awareness of the accessibility challenges in mathematcs MOOCs. ACM International Conference Proceeding Series, Part F132203. https://doi.org/10.1145/3144826.3145435

Rauf, I., Troubitsyna, E., \& Porres, I. (2019). A systematic mapping study of API usability evaluation methods. Computer Science Review, 33, 49-68.

https://doi.org/10.1016/J.COSREV.2019.05.001

Rumanová, L., \& Drábeková, J. (2017). View of teaching the mathematics of production possibilities curve. ACM International Conference Proceeding Series, 213-217. https://doi.org/10.1145/3175536.3175559

Salas, J., Chang, A., Montalvo, L., Núñez, A., Vilcapoma, M., Moquillaza, A., Murillo, B., \& Paz, F. (2019). Guidelines to Evaluate the Usability and User Experience of Learning Support Platforms: A Systematic Review. Communications in Computer and Information Science, 1114 CCIS, 238-254. https://doi.org/10.1007/978-3-030-37386-3_18

Sánchez, M., Garrote, L., \& Escolnao, J. (2019). Aprendizaje y enseñanza de las matemáticas. (C) Editorial Síntesis, S. A. https://www.sintesis.com/data/indices/9788491712657.pdf

Sarkar, P., Kadam, K., \& Pillai, J. S. (2019). Collaborative Approaches to Problem-Solving on Lines and Angles Using Augmented Reality. 2019 IEEE Tenth International Conference on Technology for Education (T4E), 193-200. https://doi.org/10.1109/T4E.2019.00-24

Singh, M., \& Jha, R. C. (2019). Object-Oriented Usability Indices for Multi-Objective Demand Side Management Using Teaching-Learning Based Optimization. Energies 2019, 12(3), 370. https://doi.org/10.3390/EN12030370

Toda, A. M., Do Carmo, R. S., Campos, V., Da Silva, A. L., \& Brancher, J. D. (2015). Evaluation of SiGMa, an empiric study with Math teachers. Proceedings - Frontiers in Education Conference, FIE, 2015. https://doi.org/10.1109/FIE.2015.7344073

Tomaschko, M., \& Hohenwarter, M. (2017). Integrating mobile and sensory technologies in mathematics education. ACM International Conference Proceeding Series, 39-48. https://doi.org/10.1145/3151848.3151866

Torres-Carrion, P. V., Gonzalez-Gonzalez, C. S., Aciar, S., \& Rodriguez-Morales, G. (2018). Methodology for systematic literature review applied to engineering and education. IEEE Global Engineering Education Conference, EDUCON, 2018-April, 1364-1373. https://doi.org/10.1109/EDUCON.2018.8363388

Tsouccas, L., \& Meletiou-Mavrotheris, M. (2017). Enhancing the Technological, Pedagogical and Content Knowledge (TPACK) of in -service primary teachers use of tablet use technologies. ACM International Conference Proceeding Series. https://doi.org/10.1145/3136907.3136951

Urrútia, G., \& Bonfill, X. (2010). PRISMA declaration: A proposal to improve the publication of systematic reviews and meta-analyses. Medicina Clinica, 135(11), 507-511.

https://doi.org/10.1016/j.medcli.2010.01.015

Varsaluoma, J., Väätäjä, H., \& Walsh, T. (2016). Exploring motivational aspects and user experience of mobile mathematics learning service in South Africa. AcademicMindtrek 2016 - Proceedings of the 2oth International Academic Mindtrek Conference, 159-168. https://doi.org/10.1145/2994310.2994369 
Vieira, E. A. O., Silveira, A. C. da, \& Martins, R. X. (2019). Heuristic evaluation on usability of educational games: A systematic review. Informatics in Education, 18(2), 427-442. https://doi.org/10.15388/infedu.2019.20

Vlachogianni, P., \& Tselios, N. (2021). Perceived usability evaluation of educational technology using the System Usability Scale (SUS): A systematic review. Journal of Research on Technology in Education. https://doi.org/10.1080/15391523.2020.1867938

Wan-Sulaiman, W. N. A., \& Mustafa, S. E. (2019). Usability Elements in Digital Textbook Development: A Systematic Review. Publishing Research Quarterly, 36(1), 74-101. https://doi.org/10.1007/s12109-019-09675-3

Wang, J., Antonenko, P., Celepkolu, M., Jimenez, Y., Fieldman, E., \& Fieldman, A. (2018). Exploring Relationships Between Eye Tracking and Traditional Usability Testing Data. International Journal of Human-Computer Interaction, 35(6), 483-494. https://doi.org/10.1080/10447318.2018.1464776

Weichbroth, P. (2020). Usability of mobile applications: A systematic literature study. IEEE Access, 8, 55563-55577. https://doi.org/10.1109/ACCESS.2020.2981892

Weinerth, K., Koenig, V., Brunner, M., \& Martin, R. (2014). Concept maps: A useful and usable tool for computer-based knowledge assessment? A literature review with a focus on usability. Computers \& Education, 78, 201-209. https://doi.org/10.1016/j.compedu.2014.06.002

Yağmur, S., \& Çakır, M. P. (2016). Usability Evaluation of a Dynamic Geometry Software Mobile Interface Through Eye Tracking. Lecture Notes in Computer Science (Including Subseries Lecture Notes in Artificial Intelligence and Lecture Notes in Bioinformatics), 9753, 391-402. https://doi.org/10.1007/978-3-319-39483-1_36

Yáñez-Gómez, R., Cascado-Caballero, D., \& Sevillano, J. L. (2017). Academic methods for usability evaluation of serious games: a systematic review. Multimedia Tools and Applications, 76(4), 5755-5784. https://doi.org/10.1007/s11042-016-3845-9

Yáñez-Gómez, R., Font, J. L., Cascado-Caballero, D., \& Sevillano, J. L. (2019). Heuristic usability evaluation on games: a modular approach. Multimedia Tools and Applications, 78(4), 49374964. https://doi.org/10.1007/s11042-018-6593-1 